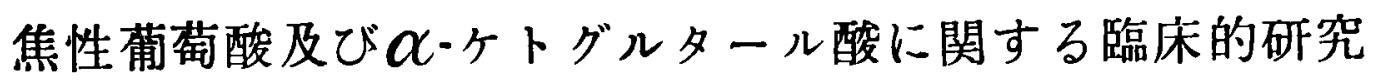

\author{
第 II編 \\ グルタミン酸ンーダを負荷した場合の血液, 腰椎髓液, 脳室髄 \\ 液中の焦性葡萄酸及び \\ 岡山大学医学部神経精神医学教室（主任 : 奥村二吉教授) \\ 上永広済 \\ [昭和 33 年 10 月 1 日受稿]
}

\begin{abstract}
緒 言
グルタミン酸の治療効果, 殊に神経・精神科領域 における研究報告は，同時にグルタミン酸の脳にお けろ作用，並びに代謝機転の解明と相まつて，興味 ある課題として追求されつつある。㧕くグルタミン 酸が臨床的に使用されるに至つたのは，Krebs1)2) が脳切片を用いてアンモ二アを消失せしめ，グルタ ミンを生ぜしめた事に始る。 ついで Waelsch3), Price4) \& Putnam4) 等がグルタミン酸を投与して, てんかん小発作注鎮应效果のある事を報告し, 又て れとは別に中5) は既にグルタミン酸が，脳䯠のアン モ二ア生成を抑制し，脊椎腔内注射でてんかんの発 作を抑制する事を証明している. 又之等より発展し $\tau, Z$ immerman 6778899$)$ 等は精神薄弱者の知能改善に 効果がある事を強調し，更にこの種の臨休知見は極 めて多くなされつつあるが，一方ての試みに関して は又批判的な意見も少くない，林等10)はグルタミ ン酸を脳組織に注入する事に依り，被㨍を起す事を 報告し，以来一連の研究が続けられている．又一方 に於いて，之等臨床的知見と相まつて，脳組織にお けるグルタミン代謝の機構が漸次検討されつつある が，グルタミン酸の関与する臨床的効果は頗る多岐 に亘り，その複雑な代謝過程が想定されるので，本 物質の臨床的効果を説明するに足る結論を得るに至 つていない，私は第 1 編並び第 2 編において夫々

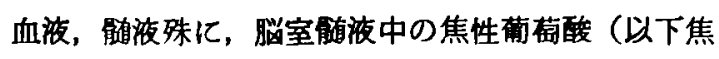
ブと略記する）並びに a-ケトグルタール酸（以下 ル・ケトグと略記する)について検索し，髄液におけ るケト酸の代謝並びに脳代謝との関㖒性について二, 三のの考察を試みたが, 本編においては、グルタミ ン酸の作用機転を，てれら精質中間代謝産物として，
\end{abstract}

脳において重要な位置を占めると共に，蛋白質及び アミ/酸代謝と密接に慗る両ヶト酸の血液, 噵液就 中脳室䯋液における消長を通して検討し，引続いて 髄液における両ケト酸の意義につき若千の考察を試 みた。

\section{実 方 法}

焦ブ並びに $\alpha$-ケトグの測定方法は第 1 編に記し たと同様に，Friedeman-Haugen 法を改良した鳥 間・清水氏法に従つた。

\section{実施}

先つ身体的に健常と認められる分裂病者 7 例につ いて，特に精神的興䒾の激しい者を避け，1 日量15 瓦のグルタミン酸ソーダを 5 日間に亘り経口投与し

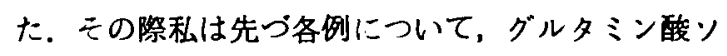
一ダ投与前の空腹安静時における血中焦ブ量及び， $\alpha$-ケトグ量を測定し，次いで服楽開始後 4〜5日 後, 安静時における両ケト酸を測定し, 更にグルタ ミン酸ソーダの全量を経口投与後直ちに, 脳手術 （ロボトミ一）を行い，第 1，2 編における場合同様， 略同時に血液、腰椎骮液、脳室路液を採取し各々に ついて両ケト酸の測定を行つた。

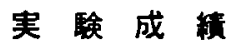

1）グルタミン酸ソーダ負荷前後における安静時， 血中焦ブ量並びに $\boldsymbol{x}$ ーケトグ量.

成績：実験成績は 1 括して第I表に示した。即 ち表に見る如く，焦ブはグルタミン酸ンーダ投与後 5 例中 3 例（No. 1，No. 2, No.5）に稍々增加を 認めたが，他は稍く減少した。 ルーケトグ冒は 5 例 中 3 例（No. 1，No.4，No.5）飞蛏度上并，他は梢， 减少する傾向を認めた。然し乍ら安静時における両 
第 1 表 クルタミン酸ンータ負荷前後に於

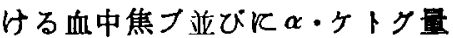

\begin{tabular}{|c|c|c|c|c|c|c|}
\hline No. & 氏名 & 性別 & 年令 & $\frac{\text { 前 }}{\text { 後 }}$ & $\begin{array}{c}\text { 焦 ブ 量 } \\
\mathrm{mg} / \mathrm{dl}\end{array}$ & $\begin{array}{c}\alpha \cdot \nvdash 卜 \\
ケ \text { 量 } \\
\mathrm{mg} / \mathrm{dl}\end{array}$ \\
\hline \multirow{2}{*}{1} & \multirow{2}{*}{ 枝O } & \multirow{2}{*}{$\delta$} & \multirow{2}{*}{49} & \multirow{2}{*}{$\frac{\text { 前 }}{\text { 後 }}$} & 0.52 & 0.32 \\
\hline & & & & & 0.66 & 0.36 \\
\hline \multirow{2}{*}{2} & \multirow{2}{*}{ ○尾 } & \multirow{2}{*}{$\hat{\delta}$} & \multirow{2}{*}{45} & \multirow{2}{*}{$\frac{\text { 前 }}{\text { 後 }}$} & 0.76 & 0.45 \\
\hline & & & & & 0.92 & 0.33 \\
\hline \multirow{2}{*}{3} & \multirow{2}{*}{ 島 0} & \multirow{2}{*}{ \$ } & \multirow{2}{*}{35} & \multirow{2}{*}{$\frac{\text { 前 }}{\text { 後 }}$} & 0.68 & 0.42 \\
\hline & & & & & 0.60 & 0.38 \\
\hline \multirow{2}{*}{4} & \multirow{2}{*}{ О川 } & \multirow{2}{*}{ ชิ } & \multirow{2}{*}{27} & \multirow{2}{*}{$\frac{\text { 前 }}{\text { 後 }}$} & 0.83 & 0.21 \\
\hline & & & & & 0.77 & 0.30 \\
\hline \multirow{2}{*}{5} & \multirow{2}{*}{ 木O } & \multirow{2}{*}{$\hat{\delta}$} & \multirow{2}{*}{30} & \multirow{2}{*}{$\frac{\text { 前 }}{\text { 後 }}$} & 0.71 & 0.43 \\
\hline & & & & & 0.87 & 0.48 \\
\hline
\end{tabular}

ケト酸の変動は比較的微量であり，これらの間に一 定の傾向を認める事は困難であつた。

2）グルタミン酸ソーダ負荷後血液，腰椎䯕液， 脳室髉液を略同時に採取した場合に於ける各々の焦 ブ量恶びに

成䌡：実験成績は 1 括して第 2 表に揭けた。(比

第 2 表 クルタタン䣫ソーダ負荷による血 液, 髁液中の焦ブ主びに $\boldsymbol{\alpha} \cdot$ ケト グ量 $(\mathrm{mg} / \mathrm{dl})$

\begin{tabular}{|c|c|c|c|c|c|c|c|c|c|}
\hline \multirow[b]{2}{*}{ No. } & \multirow[b]{2}{*}{ 氏名 } & \multirow[b]{2}{*}{ 性別 } & \multirow[b]{2}{*}{ 年令 } & 血 & 液 & 脳室 & 䯠液 & 腰椎 & 此液 \\
\hline & & & & \begin{tabular}{|c|} 
焦ブ \\
宣
\end{tabular} & $\mid \begin{array}{ll}\alpha & \\
y & 1 \\
y & \\
& \end{array}$ & \begin{tabular}{|c|} 
焦ブ \\
量
\end{tabular} & $\left|\begin{array}{ll}\alpha & \\
y & 1 \\
y & 0\end{array}\right|$ & 焦フ & $\mid \begin{array}{l}\alpha \cdot \\
\boldsymbol{y} \\
\not\end{array}$ \\
\hline 1 & 平 & 今 & 45 & 0.92 & 24 & & $19{ }^{\prime}$ & 0.68 & 0.52 \\
\hline 2 & ○井 & $\hat{\delta}$ & 49 & 0.89 & .43 & 0. & .69 & 0.82 & 0.36 \\
\hline 3 & 島 $\mathrm{O}$ & $\delta$ & 35 & 1.21 & .29 & 68 & 2.03 & 0.68 & 0.30 \\
\hline 4 & O板 & $\delta$ & 35 & 18 & 034 & 80 & 2.15 & 0.73 & 0.27 \\
\hline 5 & 小○ & to & 27 & 0.75 & 52 & 0.80 & 2.31 & 0.69 & 0.30 \\
\hline 6 & O本 & $\widehat{\delta}$ & 25 & 1.04 & 0.52 & 0.85 & 1.85 & 0.64 & 0.21 \\
\hline 7 & 木O & $\hat{\delta}$ & 30 & 1.04 & .61 & 0.83 & 1.87 & 68 & 0.38 \\
\hline
\end{tabular}

較のため特に楽物負荷する事なく採取した夫々の部 位における両ヶト酸湘定值を対照として，第 1 編か ら第 3 表として掲けた。）即ちグルタミン酸ソーダ， 1 日最 $15 \mathrm{gr}, 5$ 日間に亘つて経口投与を行つた分裂 病者, 7 例の血中焦ブ量平均估は $1.00 \pm 0.06 \mathrm{mg} / \mathrm{dl}$
第 3 表 （対＼cjkstart照）

\begin{tabular}{|c|c|c|c|c|c|c|c|c|c|}
\hline \multirow[b]{2}{*}{ No. } & \multirow[b]{2}{*}{ 氏名 } & \multirow[b]{2}{*}{ 性别 } & \multirow[b]{2}{*}{ 年令 } & \multicolumn{2}{|c|}{ 血 液 } & \multicolumn{4}{|c|}{ 脳室 铣液腰椎 髄液 } \\
\hline & & & & \begin{tabular}{|c} 
焦ブ \\
量
\end{tabular} & $\mid \begin{array}{l}\alpha \cdot \\
\zeta \quad \\
y\end{array}$ & 焦フ & $\left|\begin{array}{ll}\alpha & \\
y & 1 \\
y\end{array}\right|$ & 焦フ & $\mid \begin{array}{l}\alpha \\
y \\
y\end{array}$ \\
\hline 1 & $\mathrm{O}$ & $\hat{\delta}$ & 36 & 1.56 & 0.42 & 1.08 & 0. & & 0.35 \\
\hline 2 & O岡 & \$ & 35 & 1.41 & 0.65 & 0. & 1 & 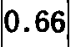 & 0.22 \\
\hline 3 & 木O & & 30 & 1.39 & 0.57 & (5 & 1.2 & 0.02 & 0.30 \\
\hline 4 & O上 & $\hat{\delta}$ & 43 & 1.13 & 59 & |' & ] .1 & 1.20 & 0.79 \\
\hline 5 & 今० & 우 & 54 & 1.24 & 0.48 & 1 & 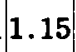 & 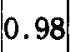 & 0.35 \\
\hline 6 & O久 & $\hat{\sigma}$ & 20 & 2.08 & 1.27 & 0. & 1.5 & 3 & 1.01 \\
\hline 7 & 提O & $T$ & 29 & 1.00 & . & & 2 & 0.8 & 0.24 \\
\hline 8 & O本 & $\delta$ & 29 & 0.76 & 0.2 & 0.68 & 0.9 & 0.60 & 0.27 \\
\hline 9 & 西O & s & 40 & 1.03 & & & & & 0.71 \\
\hline
\end{tabular}

$(0.75 \sim 1.21 \mathrm{mg} / \mathrm{dl}), \quad \alpha$ ケケグ量は $0.41 \pm$ $0.06 \mathrm{mg} / \mathrm{dl}(0.24 \sim 0.61 \mathrm{mg} / \mathrm{dl})$ である，腰椎䯣液 に就いては，焦ブ量平均值 $0.69 \pm 0.02 \mathrm{mg} / \mathrm{dl}(0.64$ 〜. $82 \mathrm{mg} / \mathrm{dl}), \alpha$ ケトグ量は $0.35 \pm 0.03 \mathrm{mg} / \mathrm{dl}$ $(0.21 \sim 0.52 \mathrm{mg} / \mathrm{dl})$ であり，脳室䯙液については， この焦ブ量は $0.80 \pm 0.02 \mathrm{mg} / \mathrm{dl}(0.68 \sim 0.85 \mathrm{mg} / \mathrm{dl})$ x 一ケトグ量は $1.83 \pm 0.13 \mathrm{mg} / \mathrm{dl}(1.19 \sim 2.31$ $\mathrm{mg} / \mathrm{dl}$ ) である.これらの值は，既に第 1 .第 2 編にお いて経験したと㕃様に，焦ブ量は血液に多く，次いで

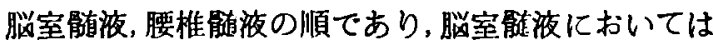
腰椎骮液の焦ブ量より平垎約 $0.11 \mathrm{mg} / \mathrm{dl}$ の增加を

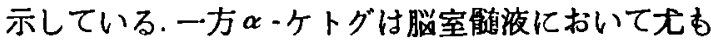
高い濃度を示し，血液腰椎髄液におりる濃度と較べ 比較的高い值を示している，即ちこの場合血中浱度 の約4.5偕，腰椎夥液濃度の約 5.2 倍と云う值を示し ている．次にこれら各ふの測定值を第 2 表に揭けた 対照檤と比較すると，血液並びに腰椎䑷液に関して は，両ヶト酸值共に著しい変量は見られないが，平 均俻はグルタミン酸ソーダ投与の場合に稍々減少す る傾向が見られる。睬室能有液に就いては，焦ブ量は 血液及び腰棑骴液における場合と同様に稍々減少傾 向が見ら北たか，逆に $\boldsymbol{\alpha}$ 一ケトグ量は比較的上昇傾 向を認め，推計学的に対照之の間に596危険率を 以て有意の差を認めた。今両ヶト酸について各部位 に於ける分散を見ると第 4 表，第 5 表に示す通りで ある。 


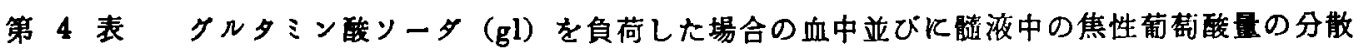

\begin{tabular}{|c|c|c|c|c|c|c|c|c|c|c|c|}
\hline $\begin{array}{l}\text { 試 } \\
\text { 料 }\end{array}$ & & $\mathrm{mg} / \mathrm{dl}$ & $0 \sim 0.19$ & $0.2 \sim$ & $\mid 0.4 \sim$ & $\left.\right|^{0.6 \sim} 0.79$ & $0.8 \sim$ & $\begin{array}{l}1.0 \sim \\
0.19\end{array}$ & $9 \mid \begin{array}{r}1.2 \sim 1.39 \\
\end{array}$ & $\mid \begin{array}{l}1.4 \sim 1.59 \\
\quad 1.59\end{array}$ & $\mid \begin{array}{l}1.6 \sim 1.79 \\
\quad 1.9\end{array}$ \\
\hline 血 & 射 & 照 & 0 & 0 & 0 & 1 & 0 & 3 & 2 & 2 & 1 \\
\hline 液 & & & 0 & 0 & 0 & 1 & 2 & 3 & 1 & 0 & 0 \\
\hline 脸睡 & 対 & 照 & 0 & 0 & 0 & 5 & 0 & 2 & 0 & 0 & 1 \\
\hline 室液 & & & 0 & 0 & 0 & 2 & 5 & 0 & 0 & 0 & 0 \\
\hline 腰笓 & 対 & 照 & 0 & 0 & 0 & 5 & 3 & 0 & 1 & 0 & 0 \\
\hline 椎液 & & & 0 & 0 & 0 & 5 & 2 & 0 & 0 & 0 & 0 \\
\hline
\end{tabular}

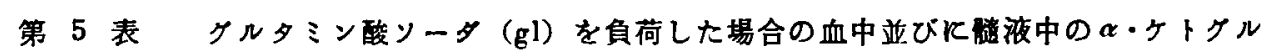
タール酸量の分散

\begin{tabular}{|c|c|c|c|c|c|c|c|c|c|c|c|c|c|c|c|c|}
\hline $\begin{array}{l}\text { 試 } \\
\text { 料 }\end{array}$ & & $\mathrm{mg} / \mathrm{dl}$ & $\begin{array}{l}0 \sim \\
0.19\end{array}$ & $\begin{array}{l}0.2 \\
\sim \\
0.39\end{array}$ & $\begin{array}{l}0.4 \\
\widetilde{0.59}\end{array}$ & $\begin{array}{c}0.6 \\
\tilde{0.79}\end{array}$ & $\begin{array}{c}0.8 \\
\tilde{0.99}\end{array}$ & $\begin{array}{c}1.0 \\
\sim \\
1.19\end{array}$ & $\begin{array}{c}1.2 \\
\sim \\
1.39\end{array}$ & $\begin{array}{c}1.4 \\
\sim \\
1.59\end{array}$ & $\begin{array}{l}1.6 \\
\sim \widetilde{1.79}\end{array}$ & $\begin{array}{c}1.8 \\
\sim \\
1.99\end{array}$ & $\begin{array}{c}2.0 \\
2.19\end{array}$ & $\begin{array}{c}2.2 \\
2.39 \\
2.39\end{array}$ & $\begin{array}{r}2.4 \\
\sim \\
2.59 \\
\end{array}$ & $\begin{array}{c}2.6 \\
2 \tilde{2.79}\end{array}$ \\
\hline 血 & 对 & 照 & 0 & 2 & 4 & 1 & 1 & 1 & 0 & 0 & 0 & 0 & 0 & 0 & 0 & 0 \\
\hline 液 & \multicolumn{2}{|c|}{ gl } & 0 & 3 & 3 & 1 & 0 & 0 & 0 & 0 & 0 & 0 & 0 & 0 & 0 & 0 \\
\hline 脳賄 & 対 & 照 & 0 & 0 & 0 & 1 & 1 & 1 & 1 & 0 & 1 & 1 & 1 & 1 & 0 & 0 \\
\hline 室液 & \multicolumn{2}{|c|}{ gl } & 0 & 0 & 0 & 0 & 0 & 0 & 0 & 0 & 0 & 1 & 2 & 2 & 1 & 0 \\
\hline 腰䯣 & 対 & 照 & 0 & 3 & 3 & 0 & 2 & 1 & 0 & 0 & 0 & 0 & 0 & 0 & 0 & 0 \\
\hline 椎液 & \multicolumn{2}{|c|}{ gl } & 0 & 6 & 1 & 0 & 0 & 0 & 0 & 0 & 0 & 0 & 0 & 0 & 0 & 0 \\
\hline
\end{tabular}

\section{考按}

以上 2 項目に亘つて，私は分裂病者にグルタミン 酸ソーダを経口的に負荷し，夫々負荷前後における 安静時血中焦ブ量並びに $\boldsymbol{\alpha}$-ケトグ冒を測定し，次 いで各例に就いてロボトミーを行い，略同時にこの

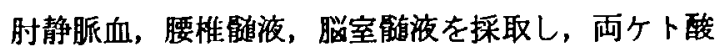
の泪定を行つた．以下これらの結果について若千の 考察を試みた。

グルタミン酸が脳において如何なる機転を演ずる かと云う問題に関しては，既に多数の報告並びに仮 説が為されているが，今日尚一定の見解には到つて いない.グルタミン酸の脳内代謝に於ける重要性は, 既にグルタミン酸の脸内分布濃度に依つても暗示さ れるが，グルタミン酸及び，グルタミンは兴の遊離 a-Amino-N の80\%に及び，この浱度は血清の15倍 にも達する11)。然し年ら脸内におけるグルタミン代 謝の特異性を，それらに関する種々の仮説に依つて も説明し尽す事は出来ない．例えばインシュリン衝 慗療法の際の低血糖性昏睡に対して，これに覚醒効 果を与える事は Braitinger ${ }^{12)}$ Zeise ${ }^{13)}$ Bay reuther ${ }^{14)}$ Osterberg ${ }^{15)}$ 等の報告に依つて明らかである，この 場合グルタミン酸から荷萄糖が発生する事が考えら
机る，しかし同様な作用を示す P-amino 安息香 酸加葡萄糖は生じない. Mayer-Gross 及び Wal-

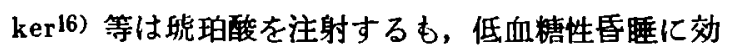
果がない所から，前記の葡萄糖への転化過程を否定 している. Weilmalherbe17)22）はこの覚醒作用を、 グルタミン酸のアドレナリン様刺戙作用に由来する あのとしており，Waelsch23) はグルタミン酸と Amphetamine の作用における類似点を挙けている. 之等に対して Mayer-Gross 及び Walker は夫々の 立場加反論している. 又脳切片について in vitro におけるグルタミン酸の酸化す昏睡作用に対する明 瞭な説明とはされていない，即ちかかる効果は他の アミノ酸, 例えば glykokoll にも見られるがこれ らのアミノ酸は in vitroで酸化されない. 更に現 在迄一般化認められているグルタミン酸の作業仮設 の内, 尤も重要視されているものはアンモニア解毒 に関するあのであるが,これは Krebs, Weilmalherbe24)25) 等に依ると、グルタミン酸はアンモニア を結合し，グルタミンを生ずると云われている，既 に脸に於てアンモニアが生ずる事は知られているが， Waelsch に依ると、この仮設は肝生昏睡の説明と して用いられているが，彼は肝より掌ろ大脸に於け る代謝に好影響を与えるすのと考え，次の 3 つの可 
能性を挙げている，即ちグルタミン酸は畄で酸化さ 机る唯一のアミノ酸であり，てれは脱厂ミノされて， ๔ーケトグルタール酸となり T.C. A cycle に入り エネルギー源になり，又グルタミン酸はアセチール コリンの合成及び，肝・堅その他の組織における陽 イオンの輸送にあ必要である点, 及びアンモ二アを 結合してグルタミンになると云う点である。しかし こ机らを以て晸癖発作，或いは進行性筋ヂストロフ 1一，其他グルタミン酸の臨木的効果の多くを説明 する事は尚困難である，更にグルタミン酸か敛のア ンモニアの調節に参与するとした場合, グルタミン 酸は脳中に達せねばならないが，一般に脳・血液関 閏はグルタミン酸によつて破られる事なく，脳中の グルタミンの上昇は見ら机ても゙ルタミン酸量は 変化を認められないあのの様である. 又如何なる機 転に依つてグルタミン酸が脳化達するであろうかと 云う点に関しては，大量のグルタミン酸は T.C.A cycle を通り, glucose から大量につくら㣗得る が26)27），脳・血液関門を通過するグルタミンの分解， 更に Amino 転位, $\boldsymbol{a}$ 一ケトグからの酸化的逆反応 に依つてあ作られる可能性があるが，ての場合グル タミンの分解については，アンモ二ア結合の終末産 物としての機能か存すると考えられるので，かかる 転換は理解し難いものとされている。

又脳化達するグルタミン酸は, 恐らくは何等かの 形で血液に依つて禣給される事が考えられるが，未 だ説明されていない. KlingmüllerとVogelgesang28) に依机ば，グルタミン酸の静脈内注射に依つて，血 中焦ブ量が消費され， $\alpha$-ケトグ量の增加を来す事 が報告さ扎，血液を通じてのグルタミン酸の補給作 用に何等汃整りのある事を示している。

私の行つた実験結果即ち、グルタミン酸ソーダの 経口投与前後の安静時血中両ヶト酸值の変化は Klingmüller 及び Vogelgesang 等の結果之は必ず しも一致するものではなかつたが，引続いて被験者 に脳手術を行い，略同時に血液，腰椎並びに脳室骮液 を採取し，両ヶト酸を測定した場合，血液並びに腰 椎能液についてむかかる傾向を認めなかつた，然る に脳室骮液に関しては，二の焦ブ量は対照に柼べ稍 々減少傾向を示したが，aーケトグ量は反つて上䄯

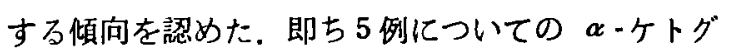
平均値は $1.83 \pm 0.02 \mathrm{mg} / \mathrm{dl}$ であり,この值は私が 現在迄に測定した脳室随液中の $\boldsymbol{\alpha}$-ケトグ量の平均 值の内尤ま高い值を示している。即ち第 1 編で示し た対照群 8 例の平均値は $1.47 \pm 0.17 \mathrm{mg} / \mathrm{dl}$ であり,
第 2 編で示したイソミタール0.5瓦静脈内注射後の 7 例における平均值は $1.64 \pm 0.05 \mathrm{mg} / \mathrm{dl}$ ，クロー ルプロマジン $100 \mathrm{mg}$ 筋注後の 6 例の平均值は 1.28 $\pm 0.26 \mathrm{mg} / \mathrm{dl}$ である. 即ちグルタミン酸ンーダの 経口的投与に依つて，脳室䯣液の $\alpha$-ケトグの上昇 傾向が見られると云う事実は，今日これらケト酸の 脳室におけにおける生理的意義が必ずしむ明らかに されていないとは云え，睢液が脳の組織液と考えら れる現在,この事は脳に於ける糖質代謝とグルタ ン酸代謝の祭りを示㖫するものであり，グルタミン 酸の脳化対する作用機転の一面を示すむのと考えれ ゲ興味深い，勿論との事を以てグルタミン酸の臨床 的効果を説明する資料とするには程遠いにしてす， 例えば，インシュリン昏睡に際し，脳中のてれら楉 質中間代謝産物は速か儿消失すると云われる29）事 を考虑すれ机こ机らの経路を通してでルタミン酸が インシュリン昏睡覚醒機転に参加する可能性む考え られる.しかしインシェリン昏睡は時に0.5 1.25 位の少量のグルタミン酸を用いる事に依つても覚醒 可能であると云う点, 或いはインシェリンによる深 い低血糖性昏睡時にもダイコクネズミ脳のグルタミ ンとグルタミン酸の総量は20 25\%低下するに過ぎ ない等30)の事加ら，脳は普通 エネルギ一産生基犋 として葡葡粕の代りにグルタミン酸を利用しないの ではないかと云う結果を来すか，Quastel 及び Wheatley31 等は in vitro の実験においてグルタミ ン酸は葡萄糖の存在しない時に限り，脳組織におい て酸化されると報告しており，グルタミン酸のイン シュリン低血糖性昏睡に対する覚醒作用は，これが 脳内で酸化される唯一のアミ/酸であり32), 又脳の 組織呼吸に参加するであろう之云う可能性を示して いるが，この事は又，兴の組織液と考えられる䯣液 殊住室髄液における前述のヶト酸の変化との関連 性が考えら机興味深い所見と思わ机た。

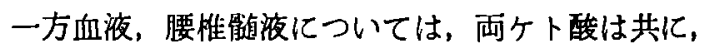
対照群の夫々と比較して寧ろ, 稍々減少する傾向が 見られた，えれは宛かむイソミタール，クロールプ ロマジン等の鎮静作用を有する薬物を負荷した場合 の様な印象を受けた。乙れは Gerlich と Remy33) が電揧汇依る疗慗について，グルタミン酸の中枢性

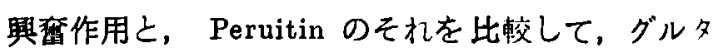
ミン酸は一回投与に於ては，非本質的な中枢興唕效 果を示すが，多くの日数に亘る投与では，疗性の 緊張が著しく減少するものであり，との效果は 3 乃 至6日の間において，比強く見られると報告して 
いる事を考虑に入れると私の実験においてもかかる 作用機転に依り，畄室艏液採取に際して，略必然的 に生ずる精神・身体的興畕がある程度抑制される事 に基いて，両ヶト酸の上昇が抑制されると考えれば 説明がつくが，とれも尚検討を要する問題である。 又 Gros 及び Kirnberger ${ }^{34)}$ 等はグルタミン酸の 経口投与に依つて肝脿の酸化能が六進する事を明ら かにしているので，乙の面からの作用効果も考えら れる.

\section{結論}

私はグルタミン酸の作用機転を血液，腰惟能液， 及び脳室䯣液中の焦ブ, 討するため，1 日量15瓦のグルタミン酸ソーダを 5 日間, 器質的矣患を認めない分裂病者に経口的に投 与し，投与前後の安静時血中両ヶト酸を測定し，引 続いて畄手術（ロボトミー）を行い，各々について 血液, 腰椎䯣液, 脳室歌液を略同時に採取し両ヶト 酸の測定を行い次の様な結果を得た。

1）グルタミン酸ソーダ負荷前後における安静時 血中両ヶト酸量を測定した結果，両物質についてグ ルタミン醉ソーダ負荷に基くと思われる一定の傾向 を見出す事は出来なかつた。

2）グルタミン酸ソーダ負荷の後, ロボトミーを 行い，血液，骮液について両ヶト酸を測定した場合

\section{文}

1) Krebs, H. A. : Biochem. J. 29, 1951, 1953.

2) Krebs, H. A., Eggleston L. V. and Hems. R. : Biochem. J. 44, 159, 1949.

3) Waelsch, Owades, Miller uud Borek : J. Biol. chem. 166, 273, 1946.

4) Price, Waelsch und Putnam : J. Am. Med. Ass. 122, 1153.

5) 台：生体の化学，4，6, 1953.

6) Zimmerman, Burgemeister \& Putnam : Arch. Neurol \& Psychit. 56, 489, 1946.

7) Zimmerman, Burgmeister \& Putnam : Am. J. Psychiat. 104, 593, 1948.

8) Zimmerman, Burgmeister \& Putnam : Psychosom. Med. 9, 175, 1947.

9) Zimmerman \& Burgmeister : Arch. Neurol. \& Psychiat. 65, 291, 1951.

10）林䇏：条件反射，4，181，1942.

11) Weil-Malherbe : Biochem. Soc. Symposia, 8, 23, 1952.
1）血中焦ブ量は $1.00 \pm 0.06 \mathrm{mg} / \mathrm{dl}$ 血中 $\alpha$-ケトグ量は $0.41 \pm 0.06 \mathrm{mg} / \mathrm{dl}$

ロ）腰椎髄液中焦ブ量は $0.69 \pm 0.02 \mathrm{mg} / \mathrm{dl}$ 腰椎喵道液中

八）脳室艏液中焦ブ量は $0.80 \pm 3.02 \mathrm{mg} / \mathrm{dl}$ 脳室盛液中 以上の各々の值を第 1 編でホした対照群と比較す ると，血液及び腰椎能液中の両ヶト酸は何れる稍減 少傾向を示した．とれはグルタミン酸ソーダの中枢 性鎮静効果或いは秆機能の改善に基くすのではない かと考えた。一方脳室䯣液に於いては，焦ブ量は対

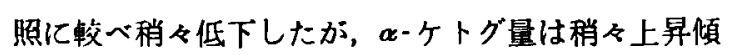
向を示した．この事はグルタミン酸が脳室䯣液のケ ト酸代謝と慗りを持つ事を示し，脳におけるグルタ ミン酸代謝との盽りを示唆するあのであり，更に脳 におけるグルタミン酸補給に関し何等かの意義を持 つものではないかと考えた。

稿を䅂るに臨み御指導御校閲を睗わつた舆村教授 飞厚く御礼申上る. 又故藤原高司教授の御指導，业

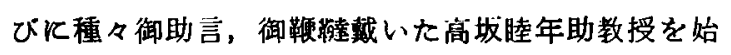
め教室員各位に对し深謝致します。更に能液採取に 当つて御協力鋇いた薄井省吾学士並びに森定諦学士 飞厚く御礼申上る。

尚本論文の要旨は第54回日本精神神経学会総会で 発表した。

\section{献}

12) Braitinger \& Zeise . Münch. Med. Wschr. 16, 834, 1952.

13) Zeise : Arch. f. Psychiatr. u. Z. Neur. 194, $1,1955$.

14) Bayreuther: Arch. f. Psychiatr. u. Z. Neur. 194, 340, 1956.

15) Bayreuther \& Osterberg : Arch. f. Psychiatr. u. Z. Neur. 194, 349, 1956.

16) Mayer-Gross \& Walker: Biochem, J. 44, 12, 1949.

17) Weil-Malherbe : Biochem. J. 30, 665, 1953.

18) Weil-Malherbe : Biochem. J. 32, 2257, 1930.

19) Weil-Malherbe : Physiol. Rev. 30, 549, 1950.

20) Weil-Malherbe - Biochem. Soc. Symposia, 8, $16,1951$.

21) Weil-Malherbe : Biochem. J. 51, 311, 1951.

22) Weil-Malherbe : J. Ment. ci. 98, 565, 1952.

23) Waelsch : Lancet 264, 1075, 1953.

24) Weil-Malherbe - Biochem. J. 32, 2257, 1938, 
25) Weil-Malherbe : J. Ment. Sci. 95, 930, 1949.

26) Waelsch : Adv. Protein chem. 6, 299, 1951.

27) Winzler, Moldave, Refelson u. Pearson : J. Biol. Chem. 199, 485, 1952.

28) Klingmüller u. Vogelgesang : Vortr. PhisiolChem, Ges. Hamburg/Saar 1-3, 9, 1953. 29) 中：神経化学, 医学㱵院, 1954.

30) Dauson, R. M. C. : Nature, Lond., 164, 1097,
1949.

31) Quastel \& Wheatley : Biochem. J. 44, 12, 1949.

32) Weil-Malherbe : J. Ment. Sci. 95, 930, 1949.

33) Gerlich u. Remy : Nervenarzt 23, 429, 1952.

34) Gros u. Kirnberger : Klin, Wschr. 31, 849, 1953.

\title{
Clinical Studies on Pyruvate and $\alpha$-Ketoglutaric Acid
}

\author{
Part 3 Changes in the Amounts of Pyruvate and $\alpha$-Ketoglutaric \\ Acid in Blood, Spinal Fluid of Lumbar Region and \\ Ventricle Fluid by the Administration of \\ Sodium Glutamate \\ By \\ Kōsai UEnaGa \\ Department of Neuro-Psychiatry Okayama University Medical School \\ (Director: Prof. Nikichi Okumura)
}

In order to study the mechanism of glutamic acids involved in the metabolisms of pyruvate and $\boldsymbol{\alpha}$-ketoglutaric acid in blood, spinal fluid of lumbar region, and ventricle fluid, the author gave oral administration of dailydosage of $1 \overline{5} \mathrm{~g}$ sodium glutamate for five days to schizophrenic patients without any apparent disorders of organs, and determined the amounts of both acids in blood when the patients were at rest both before and after the sodium glutamate administration. Then after lobotomy, blood, spinal fluid of lumbar regions and ventricle Fluid were drawn and the contents of both acids in these fluids were determined in the same manner as mentioned above. As the results :

1. In the estimations of both acids in the blood drawn both before and after the administration of sodium glutamate to the patient at rest, no fixed tendency suggestive of the effect of this drug could be recognized.

2. In the cases where lobotomy had been performed after administration of sodium glutamate and the contents of both acids were determined, and the following results were obtained :

1. The amount of pyruvate in blood $=1.00 \pm 0.06 \mathrm{mg} / \mathrm{dl}$;

the amount of $\alpha$-ketoglutarate in blood $=0.41 \pm 0.06 \mathrm{mg} / \mathrm{dl}$;

the amount of pyruvate in spinal fluid of lumbar region $=0.69 \pm 0.02 \mathrm{mg} / \mathrm{dl}$;

the amount of $\alpha$-ketoglutaric acid in spinal fluid of lumbar region $=0.35 \pm 0.03 \mathrm{mg} / \mathrm{dl}$;

pyruvate in ventricle fluid $=0.80 \pm 0.02 \mathrm{mg} / \mathrm{dl}$; and

$\alpha$-ketoglutaric acid in ventricle fluid $=1.83 \pm 0.13 \mathrm{mg} / \mathrm{dl}$.

On comparing each of these values with respective values of the control reported in Part 1 , both amounts of pyruvate and $\alpha$-ketoglutaric acid in blood and spinal fluid of lumbar region show a decreasing tendency. This phenomenon seems to be due to the tranquilizing effect of sodium glutamate on the central nervous system or to improved liver function due to this drug. On the other hand, in the case of the ventricle fluid the pyruvate content was less than that in the control, and the content of $\alpha$-ketoglutaric acid was somewhat increased. This fact seems to indicate that glutamic acid is involved in the metabolism of ketoacid in the cerebral fluid and is also associated with the glutamic acid metabolism in the brain, and also it is suggestive of some significance relative to the supply of glutamic acids in the brain. 